\title{
Coupling of energy conversion systems and wellbore heat exchanger in a depleted oil well
}

\author{
C. Alimonti, D. Berardi, D. Bocchetti and E. Soldo
}

*Correspondence:
claudio.alimonti@uniroma1.it
Università di Roma-
DICMA, Via Eudossiana 18,
00184 Rome, Italy

\begin{abstract}
The conventional geothermal power plants use the reinjection wells mostly to avoid the depletion of the geothermal reservoir gathering in the underground of the produced brine. Nevertheless, reinjection operations entail high economic costs and some risks. An alternative is the extraction of the heat without geothermal fluids production, the wellbore heat exchanger. The goal of the present paper is the analysis of the power production of the wellbore heat exchanger (WBHX) in time and the comparison between two different conversion systems of the thermal energy into electrical: the organic ranking cycle (ORC) plant and the Stirling motor. The selected case study is the oil field of Villafortuna Trecate, a medium enthalpy geothermal resource. The simulation results show a substantial decrease of the wellhead temperature in the first 6 months. After 1 year, the thermal power extracted with the WBHX is greater than $1.3 \mathrm{MW}$. The design parameters are $20 \mathrm{~m}^{3} / \mathrm{h}$ for the flow rate, outlet temperature $100.38^{\circ} \mathrm{C}$ and the inlet temperature is $40^{\circ} \mathrm{C}$. The $\mathrm{R}-\mathrm{C} 318$ has been selected as working fluid in the ORC plant: the net electrical power is $121 \mathrm{~kW}$. The air is the working fluid in the Stirling motor: the evaluated net electrical power is $152 \mathrm{~kW}$. The Stirling engine has an efficiency greater than $41 \%$ compared to a system ORC.
\end{abstract}

Keywords: Wellbore heat exchanger, Geothermal energy, Energy conversion plant, ORC, Stirling motor

\section{Background}

The conventional geothermal power plants use the brines directly (single flash power plants, dual flash power plants, dry steam power plants) or indirectly (closed loop binary plants). In both types of installations, the production and the reinjection of the fluids are carried out.

The reinjection procedure has multiple goals: to reinject in the underground the fluids that have physicochemical properties not suitable to the terrestrial ecosystems; to avoid the depletion of the geothermal reservoir gathering in the underground the produced brine; to re-establishing the underground pressure; to offset surface subsidence caused by the pressure decline due to the production.

Reinjection has long been employed in the geothermal fields utilized for power production in the Philippines, mainly because of environmental reasons, but it has also been adopted to improve reservoir performance (Stefánsson 1997). The reinjection of

D 2016 The Author(s). This article is distributed under the terms of the Creative Commons Attribution 4.0 International License (http://creativecommons.org/licenses/by/4.0/), which permits unrestricted use, distribution, and reproduction in any medium, provided you give appropriate credit to the original author(s) and the source, provide a link to the Creative Commons license, and indicate if changes were made. 
steam condensate at The Geysers in California substitutes the recharge to some degree and hence improves the performance of the Geysers reservoir (Goyal and Conant 2010). In the Larderello field, the reinjection operations have been started in 1974 with the aim of disposing of excess steam condensate. Some years later, the reinjection method was envisaged as a method for improving heat recovery of the reservoir rocks (Giovannoni et al. 1981). According to Cappetti et al. (1995), a large part of the reinjected water in Larderello reservoir has been recovered as superheated steam, with a significant increase in steam flow-rate and reservoir pressure. The reinjection experiences in Tianjin since 1996 and in Beijing since 2001 show that it is significant in controlling the lowering of reservoir pressure, and improves the heat mining of the geothermal field (Liu et al. 2006).

Reinjection operations entail high economic costs since they require the drilling and maintenance of additional wells, the treatment and the pumping of the fluids. Reinjection entails also some risks: the injected cold water could interfere with the hot waters of the production level often because of "short-circuiting" along direct flow-paths such as open fractures (Axelsson 2012), the geothermal fluids could pollute the groundwater, the corrosion and scaling in surface pipelines and in the reinjection wells, the seismicity phenomena.

The cooling of production brines is a possibility when the production wells and the reinjection ones are close. An example is decreasing of geothermal fluid temperature in the PN26 well in Palinpinon field, Philippines (Malate and O'Sullivan 1991).

The scaling and corrosion phenomena are frequent both in reinjection wells and in production ones. These phenomena are related to the chemical composition of the brine, the $\mathrm{pH}$ value, the pressure and temperature changes and the over-saturation of some dissolved minerals. Corrosion and scaling can cause the damages to pipes, the reduction of casings diameters and so an efficiency decrease of the geothermal well. Maintenance operations and additional costs will be necessary. Itoi et al. (1987) have observed the complete obstruction of the wells in the Otake field (Japan) due to silica scales.

According to Diaz (2015), there is a direct correlation between reinjection and microearthquakes in some geothermal fields especially in vapour-dominated systems and high-enthalpy dominated systems. Micro-earthquakes have been observed in the reservoirs of Darajat (Pramono and Colombo 2005), Larderello (Bolognesi 2011), The Geysers (Altmann et al. 2013), Krafla (Evans et al. 2012), Hellisheidi (Gunnarsson 2011), YanaizuNishiyama (Asanuma et al. 2014), Los Azufres (Noé et al. 2013), Los Humeros (Urban and Lermo 2013), Rotokawa (Sherburn et al. 2013), Nga Awa Purua (Sherburn et al. 2013), Salton Sea (Brodsky and Lajoie 2013) and Puna (Kenedi et al. 2010).

Flóvenz et al. (2015) reported that data from fluid injection sites in Iceland shows clearly that induced seismicity is much more common than earlier thought. In 8 of the 11 exploitation sites, seismicity related to reinjection has occurred. The magnitude of the earthquakes are normally lower than 2.0. But in the Hellisheiði field have been registered some earthquakes of magnitude up to 3.9 of $M_{\mathrm{L}}$ (Gunnarsson et al. 2015).

It has been reported that the seismic activity has possibly increased the porosity in the reservoir Darajat (Pramono and Colombo 2005), enhanced the permeability in the reservoir of Larderello (Bolognesi 2011), and induced stress changes in rock in Los Azufres field (Noé et al. 2013). 
The risk of groundwater pollution and of induced earthquakes has a strong impact on the population living in the cities close to the geothermal plants. It is important to find solutions to avoid these risks, which could induce a low social acceptance of new geothermal projects.

An alternative is the extraction of the heat without geothermal fluids production, avoiding the reinjection procedures. This solution is possible with a closed loop in which a heat carrier fluid circulates and extracts the heat from the surrounding rock (Fig. 1). The device is a deep borehole heat exchanger, the wellbore heat exchanger (WBHX) according to the acronym of Nalla et al. (2005), who has developed a numerical model to evaluate the application of the WBHX in an existing geothermal well.

Some researchers have studied the operative parameters that influence the feasibility and efficiency of the power plants based on WBHX. Among them are the geothermal gradient, the bottomhole temperature, the depth of the well, the properties and the flow rate of the selected working fluid, the thermal insulation between the two pipes that compose the heat exchanger (Kujawa et al. 2006; Davis and Michaelides 2009; Bu et al. 2012; Cheng et al. 2013, 2014).

Several studies have proposed the use of the borehole exchangers to convert the abandoned oil wells into geothermal ones (Kujawa et al. 2006; Zhang et al. 2008; Wang et al. 2009; Davis and Michaelides 2009; Bu et al. 2012; Cheng et al. 2013; Templeton et al. 2014; Cheng et al. 2014). Considering the drilling costs almost $25 \%$ of the total costs of the power plant (Hance 2005), and the high costs of closure of the oil fields, the use of the WBHX could be an economic advantage both for oil companies and for geothermal companies.

The main weakness of the deep borehole heat exchanger is a low efficiency in heat recovery compared to a conventional geothermal technology. This is due to the lower

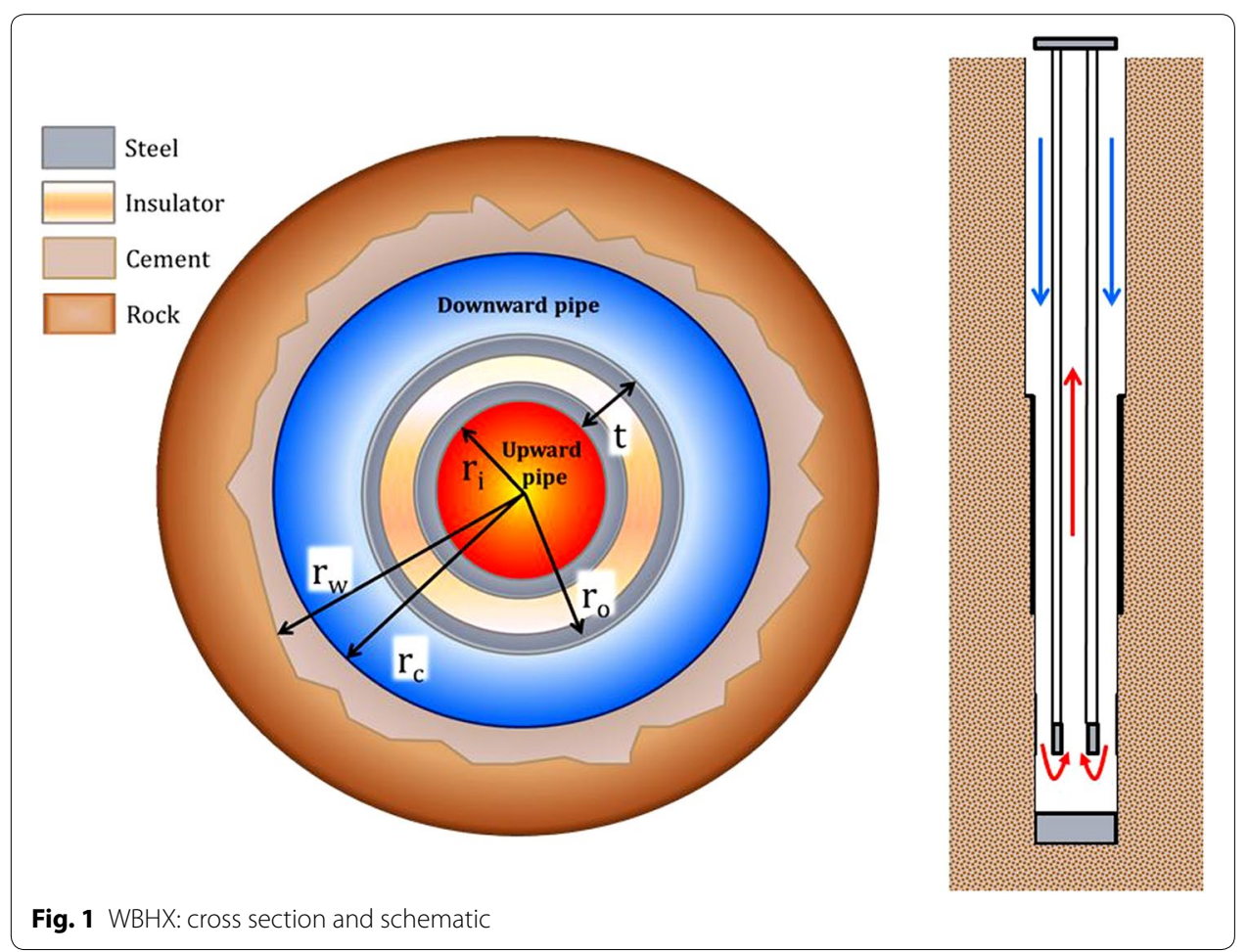


mass flow rate and to the indirect exchange of heat, which causes a lower wellhead temperature. However, the use of a WBHX could be a solution to extract heat from unconventional geothermal systems, such as magmatic or hypersaline reservoirs, where there are fluids with particular physical and chemical characteristics. The production of such fluids involve significant technical problems and high economic costs that can make non-profitable investment. The WBHX could be also an alternative to hydrofracking methods to exploit the hot dry rock reservoirs.

In a previous study (Alimonti and Soldo 2016) has been proposed the application of the WBHX in an oil field. The selected case study is the Villafortuna Trecate field, a large hydrocarbon field still active but strongly depleted. The reservoir is a medium enthalpy geothermal resource (the bottomhole temperature is $160-170{ }^{\circ} \mathrm{C}$ ) located between 5800 and $6100 \mathrm{~m}$ depth.

The feasibility of the WBHX has been studied using a numerical model. The target was the optimization of the WBHX to maximize the extracted heat. Two different heat carrier fluids were tested: diathermic oil and water, this latter has shown better heat transfer properties. Furthermore, the work by Melinder (2007) has shown that the values of thermal conductivity and volumetric heat capacity of the water are higher than for the fluids generally used as secondary working fluids. The internal diameters of the pipes were modified until a configuration that ensures greater efficiency is found in the extraction of heat for the specific case study. The results of the study highlight also the importance to consider the change in fluid properties inside the WBHX. To evaluate the conversion capacity of the ORC plant a thermodynamic model has been built, which allow testing different working fluids. The R-C318 has been selected as the best working fluid considering the thermal efficiency.

In the proposed solution, a binary cycle plant with two stage of heat exchange converts the thermal power into electricity, as an alternative of a direct binary power plant (Davis and Michaelides 2009; Bu et al. 2012; Cheng et al. 2013).

Starting from the results of the previous work another system to convert the thermal energy into electrical one has been studied: the Stirling motor. The goal is to compare the conversion capacity of the ORC plant with that of the Stirling motor.

\section{Methods}

\section{Heat transfer model}

The heat transfer phenomena between the hot rock and the water circulating in a deep borehole heat exchanger takes place by conduction and convection. In a previous study (Alimonti and Soldo 2016) the model was developed using an analytical solution of the Fourier equation and it was implemented in a $C$ computation code.

In the following paragraphs, the equations of the model are reported.

\section{Rock temperature}

Using a ground surface temperature $T_{\mathrm{o}}$ of $25^{\circ} \mathrm{C}$, the rock temperature at the depth $z$ has been evaluated using the following relation:

$$
T_{\mathrm{w}}(z)=T_{\mathrm{o}}+\mathrm{GT} \cdot z
$$

where GT is the geothermal gradient of the site. 


\section{Heat transfer in the downward pipe}

In the model, the heat transfer from the rock is due mainly to the conduction; no convection takes place. Then the heat moves still by conduction from the reservoir to the external casing of the WBHX, which is separated from the rock wall by a layer of cement. The convection takes place in the heat transfer between the casing and the water in the borehole heat exchanger.

The heat acquired by the water in the downward pipe is directly proportional to the length of the pipe $(\Delta z)$, the external radius of the borehole $\left(r_{\mathrm{w}}\right)$, the total heat exchange coefficient $\left(k_{\mathrm{t}}\right)$, the difference between the rock temperature at depth $z\left(T_{\mathrm{w}}\right)$ the temperature of the fluid in the outer pipe $\left(T_{\mathrm{f} \text {,down }}\right)$. The thermal power can be calculated with the following relation:

$$
\dot{Q}_{\text {down }}=2 \pi r_{\mathrm{w}} k_{\mathrm{t}}\left(T_{\mathrm{w}}(z)-T_{\mathrm{f}, \text { down }}\right) \Delta z
$$

The total heat transfer coefficient is the reciprocal of the total thermal resistance, which can be expressed as:

$$
R_{\mathrm{t}}=R_{\mathrm{a}}+R_{\mathrm{c}}+R_{\mathrm{s}}
$$

The three terms in Eq. (3) are the thermal resistance due to the convection into the annular space of the WBHX $\left(R_{\mathrm{a}}\right)$, the thermal resistance due to the conduction through the casings $\left(R_{\mathrm{c}}\right)$; the thermal resistance due to the conduction in the rock $\left(R_{\mathrm{s}}\right)$.

To evaluate the conductive thermal resistance in the rock the thermal conductivity of the rock $\lambda_{\mathrm{s}}$, the thermal diffusivity of the rock $a_{\mathrm{s}}$, the external radius of the well $r_{\mathrm{w}}$, and the elapsed time since the start $t^{\prime}$ must be known:

$$
R_{\mathrm{s}}=\frac{1}{2 \lambda_{\mathrm{s}}} \ln \frac{2 \sqrt{a_{\mathrm{s}} t^{\prime}}}{r_{\mathrm{w}}}
$$

This equation arises from the analytical solution of heat transfer equation given in Carslaw and Jaeger (1959). The term $2 \sqrt{a_{\mathrm{s}} t^{\prime}}$ represents the travelling distance of the temperature front. At distance $>2 \sqrt{a_{\mathrm{s}} t^{\prime}}$ in the rock the temperature is undisturbed and equal to $T_{\mathrm{w}}$.

The conductive thermal resistance of the rock (Fig. 2) increases very rapidly in the first year of operation. After the second year of work, $R_{\mathrm{s}}$ is $1.1 \mathrm{~m}^{2} \mathrm{~K} / \mathrm{W}$ and increases up to $1.2 \mathrm{~m}^{2} \mathrm{~K} / \mathrm{W}$ after 10 years. This behavior is due to the exponential growth of the interested volume of rock by the heat transfer.

To evaluate the thermal resistance $R_{\mathrm{a}}$ the radius of the external casing $r_{\mathrm{c}}$ and the convective heat transfer coefficient $h$ must be known:

$$
R_{\mathrm{a}}=\frac{1}{2 \cdot r_{\mathrm{c}} \cdot h}
$$

The convective heat transfer coefficient is calculated using the definition of the Nusselt number and a form of Dittus-Boelter equation, having assumed turbulent flow inside tubes (Davis and Michaelides 2009; Bennett and Myers 1982)

$$
h=\frac{0.023 \cdot \lambda_{\mathrm{f}} \cdot \operatorname{Re}^{0.8} \cdot \operatorname{Pr}^{0.4}}{2 \cdot r_{\mathrm{c}}}
$$




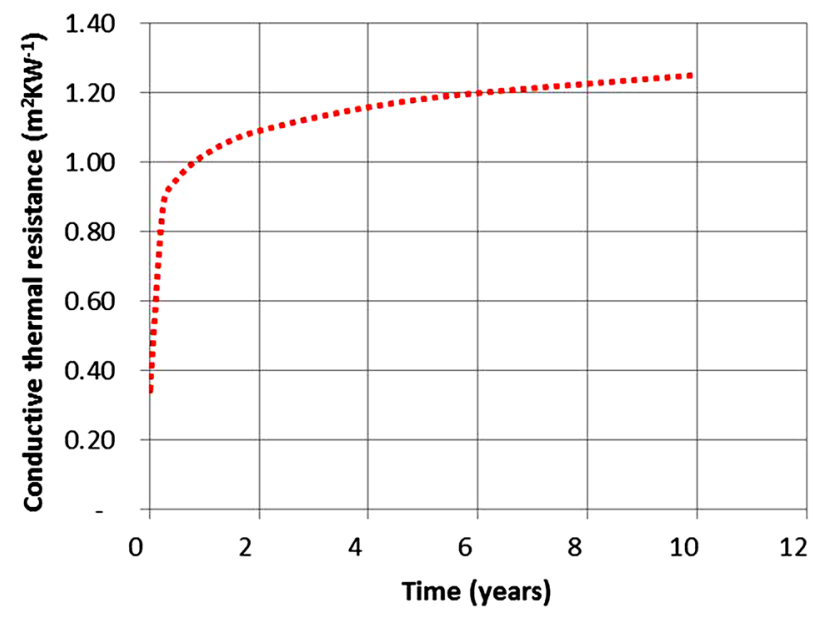

Fig. 2 The conductive thermal resistance versus time

The pipes are steel, which has a high thermal conductivity, so in the model the thermal resistance of the casings has been neglected compared to the rock resistance.

The effect of the cementing ring was studied by evaluating the mutual thermal resistance (to heat conduction) of the concrete and of the rock. The results show that, despite the thermal conductivity of the concrete being less than that of the rock, given the small thickness of the grouting layer with respect to the extension of the rock, the presence of cement is negligible. The heat resistance of the cement is $0.0233 \mathrm{~W} / \mathrm{m}^{2} \mathrm{~K}$ instead for the rock is equal to $0.11 \mathrm{~W} / \mathrm{m}^{2} \mathrm{~K}$. Therefore, the diameters of the casing and of the well are assumed to be similar.

The total heat exchange coefficient can be determined as:

$$
\frac{1}{k_{\mathrm{t}}}=\frac{D_{\mathrm{c}}}{2 \cdot \lambda_{\mathrm{s}}} \cdot \ln \frac{4 \sqrt{a_{\mathrm{s}} t^{\prime}}}{D_{\mathrm{c}}}+\frac{1}{h}
$$

\section{Heat transfer in the upward pipe}

The heated water enters in the internal pipe and flows upward exchanging the heat with the wall of the composite pipe.

The thermal power is proportional to the radius of the inner tube $\left(r_{\mathrm{i}}\right)$, the overall heat transfer coefficient $\left(k_{\mathrm{o}}\right)$, the temperature of the water in the inner pipe $\left(T_{\mathrm{f} \text {,up }}\right)$, the temperature of the fluid $\left(T_{\mathrm{f}, \mathrm{down}}\right)$ in the outer pipe, the length of the pipe $(\Delta z)$ :

$$
\dot{Q}_{\text {up }}=2 \pi r_{\mathrm{i}} k_{\mathrm{o}}\left(T_{\mathrm{f} \text {,up }}-T_{\mathrm{f}, \text { down }}\right) \Delta z
$$

Using the theory of the heat exchange in the multi-layer cylindrical wall, the total heat exchange coefficient $k_{\mathrm{o}}$ can be calculated with the relation:

$$
\frac{1}{k_{\mathrm{o}}}=\frac{r_{\mathrm{i}}}{r_{\mathrm{i}}+t} \cdot \frac{1}{h_{\mathrm{o}}}+r_{\mathrm{i}} \sum_{i=1}^{n} \ln \left(\frac{r_{\mathrm{j}+1}}{r_{\mathrm{j}}}\right) \cdot \frac{1}{\lambda_{\mathrm{j}}}+\frac{1}{h_{\mathrm{i}}}
$$

The first element in Eq. (9) is due to the convective heat transfer to the outer wall: $r_{\mathrm{i}}$ is the radius of the inner tube, $t$ is the thickness of the composite pipe, $h_{\mathrm{o}}$ is the coefficient 
of convective heat transfer to the outer wall. The second term of Eq. (9) is related to the conductive heat transfer through the composite pipe: $\lambda_{\mathrm{j}} r_{\mathrm{j}}$ are the thermal conductivity and the radius of the material (air and steel). The third element of Eq. (9) is due to the convection to the inner wall.

\section{The thermo-siphon effect}

The WBHX has been optimized to produce the maximum thermal power using the minimum electrical energy to pump the fluid in the downward pipe. This condition is achieved through the spontaneous circulation due to the thermo-siphon effect: when the fluid is heated, it goes back on top naturally through the inner tube. The pressure enhancement is due to the variation of the density that is lesser in the downward pipe than in the upward pipe.

The following relations have been used to evaluate the pressure losses:

$$
\begin{aligned}
& \Delta P=\rho g \Delta z-\Delta P_{f} \text { downward } \\
& \Delta P=-\rho g \Delta z-\Delta P_{f} \text { upward } \\
& \Delta P_{f}=f \frac{\Delta z}{D} \rho(T) \frac{v^{2}}{2}
\end{aligned}
$$

where $\Delta P_{f}$ are the friction losses, $f$ is the friction factor calculated with the explicit correlation of Churchill (1977), $\Delta z$ and $D$ are respectively the length and the diameter of the pipe, $\rho$ and $v$ are, respectively the density and the velocity of the fluid.

Considering that the pipes are very large in length, the hypothesis of none local pressure losses has been used.

\section{Energy conversion systems}

Two different systems have been selected to convert the thermal power into electrical one: an organic Rankine cycle power plant and a Stirling motor.

\section{ORC plant model}

Figure 3 shows the schematic of the ORC plant. The black lines indicate the pattern of the water, the green lines indicate the pattern of the working fluid of the ORC plant.

The hot water exiting from the deep borehole, flows through an heat exchanger and transfers the heat to the ORC's working fluid. Then the water passes in the preheater and it is re-injected into the well by means of the pump P.

The ORC's working fluid is heated up to the boiling point in the preheater $\mathrm{PH}$ and then it attains the condition of saturated vapor in the evaporator E. The saturated vapor is sent to the turbine $\mathrm{T}$ where the expansion takes place: the thermal energy is converted in kinetic and then in electrical in the generator G. Exiting from the turbine the working fluid is condensed $(\mathrm{C})$ and then it is pumped $(\mathrm{CP})$ to the preheater.

Figure 4 shows the thermodynamic cycle of the ORC plant.

Knowing the mass flow rate $\dot{m}_{\mathrm{b}}$ and the outlet $\left(T_{\mathrm{a}}\right)$ and inlet $\left(T_{\mathrm{c}}\right)$ temperature of the WBHX, the mass flow rate of the working fluid $\dot{m}_{\text {wf }}$ can be calculated using the following equation: 


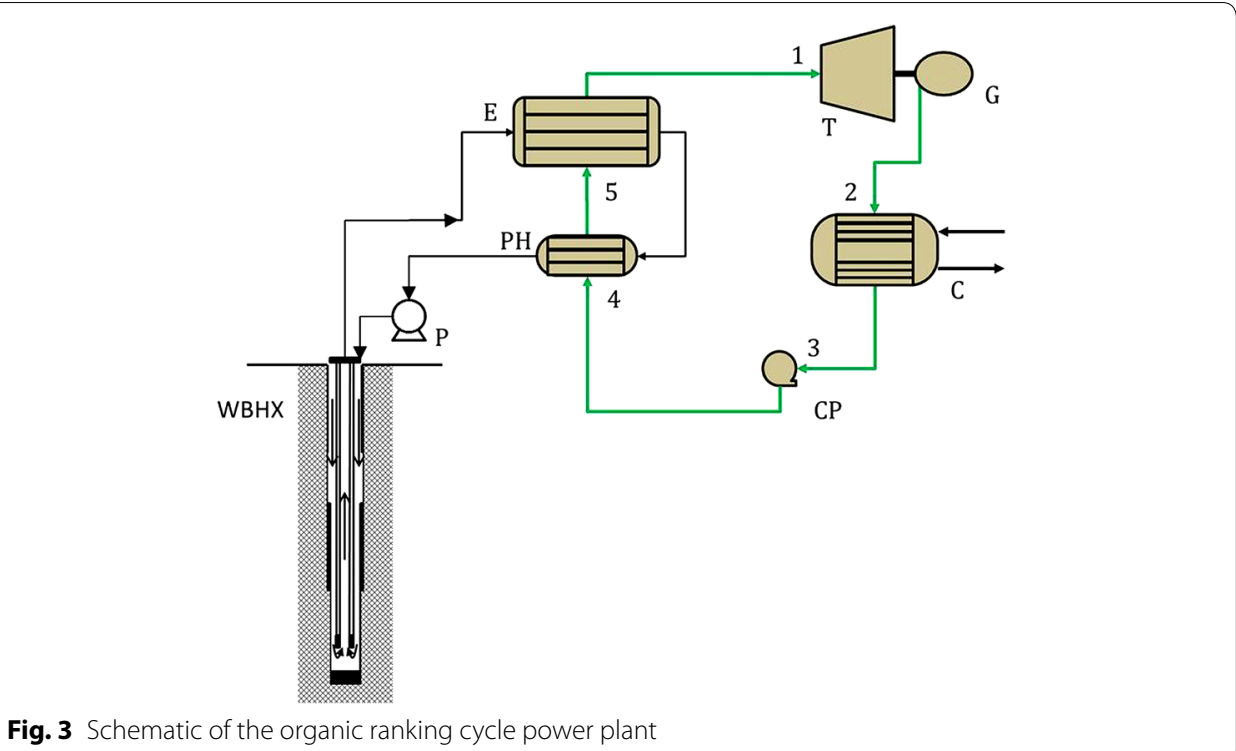

Fig. 3 Schematic of the organic ranking cycle power plant

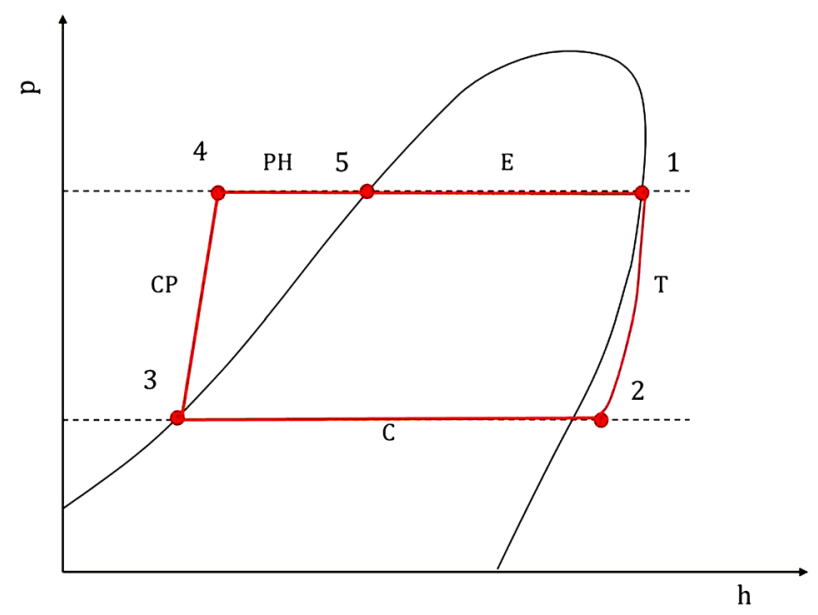

Fig. 4 Pressure-enthalpy diagram for a binary plant

$$
\dot{m}_{\mathrm{wf}}=\dot{m}_{\mathrm{b}} \frac{c_{\mathrm{p}}\left(T_{\mathrm{a}}-T_{\mathrm{c}}\right)}{h_{1}-h_{4}}
$$

where $h_{1}$ is the enthalpy at the outlet of the evaporator, $h_{4}$ is the enthalpy at the inlet of the preheater.

Indicating with $h_{2}$ the enthalpy at the inlet of the condenser $C$, the electrical power available to the turbine $\mathrm{T}$ can been evaluated using the following equation:

$$
\dot{W}_{t}=\dot{m}_{\mathrm{wf}}\left(h_{1}-h_{2}\right)
$$

The WBHX model explained in the previous paragraph evaluates the temperature of the water at the wellhead, which is the also inlet temperature at the heat exchange unit. 
The inlet temperature of water in the WBHX the exit temperature $T_{\mathrm{c}}$ of the heat carrier fluid from the heat exchanger is fixed at $40^{\circ} \mathrm{C}$. The mass flow rate of the working fluid in the ORC plant is calculated according the temperature profile in the WBHX and fixing pinch point temperature around $5{ }^{\circ} \mathrm{C}$ (Fig. 5).

The ratio of the net electrical power produced from the cycle $\dot{W}_{\text {net }}$ and the heat transfer rate in the heat exchanger unit $Q_{\mathrm{ht}}$ has been used to evaluate the thermal efficiency:

$$
\eta_{\mathrm{th}}=\frac{\dot{W}_{\text {net }}}{Q_{\mathrm{ht}}}=1-\frac{\left(h_{2}-h_{3}\right)}{\left(h_{1}-h_{4}\right)}
$$

\section{Stirling motor model}

According to Kolin et al. (2000) when compared to the classic Clausius-Rankine cycle, mostly used in the present geothermal plants, Stirling cycle offers many theoretical and practical advantages. From thermodynamic point of view, Stirling cycle is equivalent to the optimal Carnot cycle, having the highest possible efficiency. The thermodynamic Stirling motor model follows the indications of Lloyd (2009).

In Fig. 6 the pressure-volume diagram for the Stirling cycle is shown. The real cycle has a lower efficiency compared to the ideal cycle. The assumptions of an ideal Stirling cycle are the use of a perfect gas as a working fluid, absence of flow resistance, perfect regeneration, no conduction heat losses, isothermal expansion and compression, nonsinusoidal piston motion, absence of mechanical friction, dead space assumed to be zero.

The amount of the net work per cycle can be evaluated as the sum of the work done during the gas compression stage $\left(W_{\mathrm{c}}\right)$ and the work done by the gas during the expansion stage $\left(W_{\mathrm{e}}\right)$ :

$$
W_{\text {net }}=W_{\mathrm{c}}+W_{\mathrm{e}}=n R_{\text {gas }}\left(T_{\mathrm{h}}-T_{\mathrm{c}}\right) \ln \left(\frac{V_{\mathrm{max}}}{V_{\min }}\right)
$$

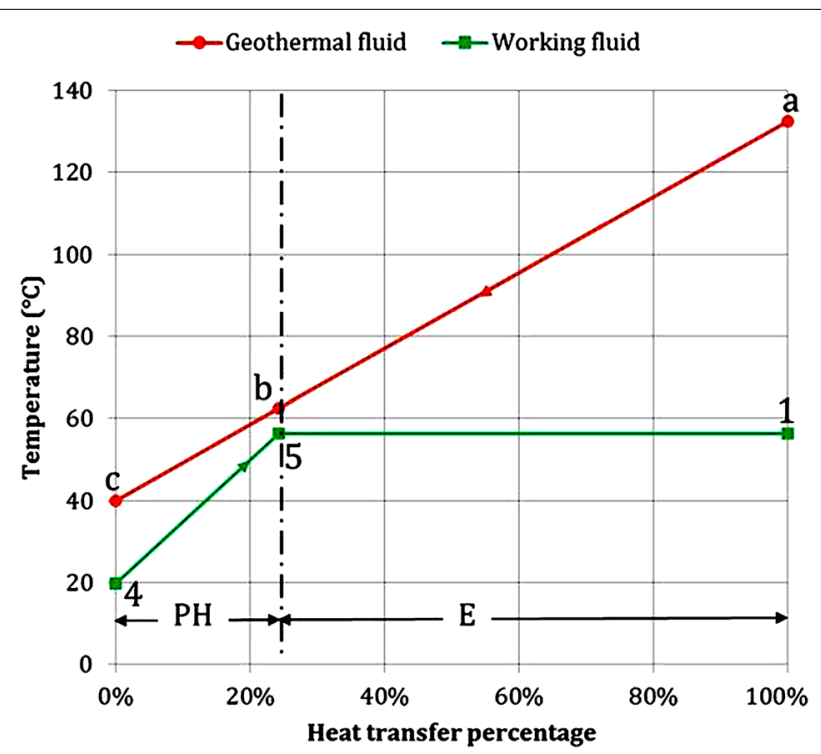

Fig. 5 Temperature-heat transfer diagram for preheater $(\mathrm{PH})$ and evaporator $(\mathrm{E})$ 


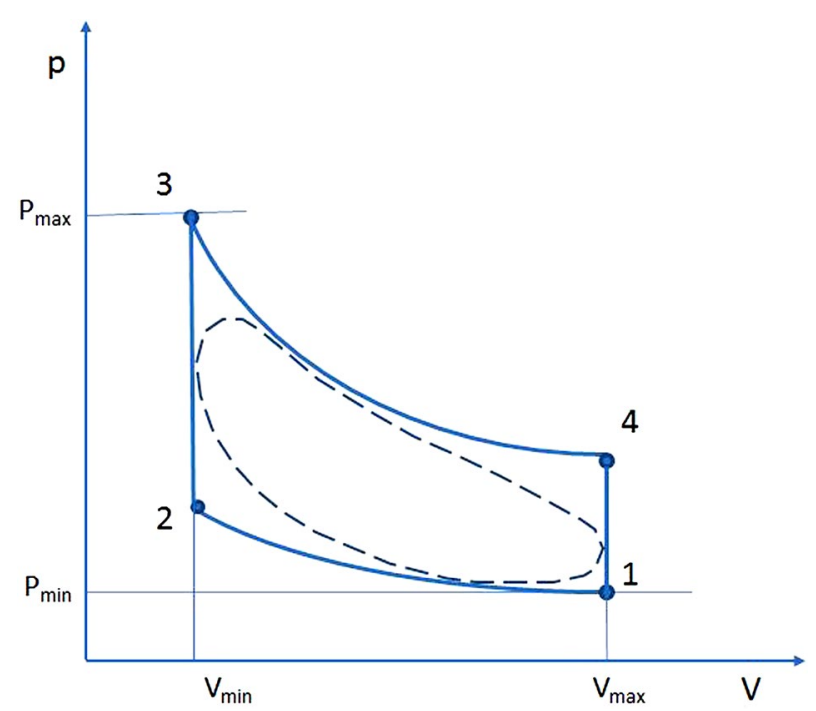

Fig. 6 Pressure-volume diagram for a Stirling cycle (continuous line ideal; broken line real)

where $n$ is the mole number of gas, $R_{\text {gas }}$ is the universal gas constant, equal to $8.314472 \mathrm{~J} /$ $\mathrm{kg} \mathrm{mol}, T_{\mathrm{h}}$ is the hot source temperature, $T_{\mathrm{c}}$ is the cold sink temperature, $V_{\max }$ is the maximum volume, $V_{\min }$ is the minimum volume.

Because in the ideal cycle the losses are absent, the produced work is equal at the supplied heat. Substituting inside Eq. (17) the value of the net work and of the supplied heat, the efficiency of the ideal Stirling cycle can be calculated as:

$$
\eta=\frac{T_{\mathrm{h}}-T_{\mathrm{c}}}{T_{\mathrm{h}}}
$$

The ideal power is the product between the net work per cycle and the number of revolutions per minute:

$$
\mathrm{EP}=\mathrm{rpm} \cdot W_{\text {net }}
$$

The reduction in power compared to the ideal cycle with no dead space can be evaluated with the empirical formula of the Schmidt factor:

$$
F_{\mathrm{s}}=0.74-0.68 \delta
$$

where the dead space ratio $\delta$ is the ratio between the total dead space volume $V_{\mathrm{d}}$ and the total volume of the gas swept by the displacer $V_{\mathrm{sw}}$ :

$$
\delta=\frac{V_{\mathrm{d}}}{V_{\mathrm{sw}}}
$$

The real power can be calculated with the following relation:

$$
\mathrm{EP}_{\text {real }}=\mathrm{EP} \cdot F_{\mathrm{s}}
$$




\section{Results}

The Villafortuna-Trecate case study was implemented following the configuration of the WBHX reported in Fig. 7.

In Table 1 are reported the sizing of the tubes and the final casing size (Alimonti and Soldo 2016). The annular space between the two pipes is filled by air and it has a thickness of $32.5 \mathrm{~mm}$. The heat transfer fluid is the water.

The reference stratigraphy is formed by $1-1.5 \mathrm{~km}$ of sand and shales and by $4.5-5 \mathrm{~km}$ of marls and limestones. Thus, the properties of rocks have been assumed to be uniform and corresponding to limestones prevailing $\left(\lambda 2.5 \mathrm{~W} / \mathrm{m} \mathrm{K}, \rho_{\mathrm{s}} 2600 \mathrm{~kg} / \mathrm{m}^{3}\right.$ and $c_{\mathrm{p}} 800 \mathrm{~J} /$ $\operatorname{kg~K)}$.

\section{Evaluation of the thermal power}

The heat transfer model has been implemented in a C computation code. Using the simulator has been studied the heat transfer in the WBHX in time: the changing of the wellhead temperature of the water, the thermal power and the required pumping power.

The wellhead temperature versus the flow rate is reported in Fig. 8. The most of reduction of the wellhead temperature occurs in the first 6 months. This phenomenon occurs because the extraction of the heat from a pure conductive system causes a progressive enlargement of the influence area of the well. The result is the reduction of the

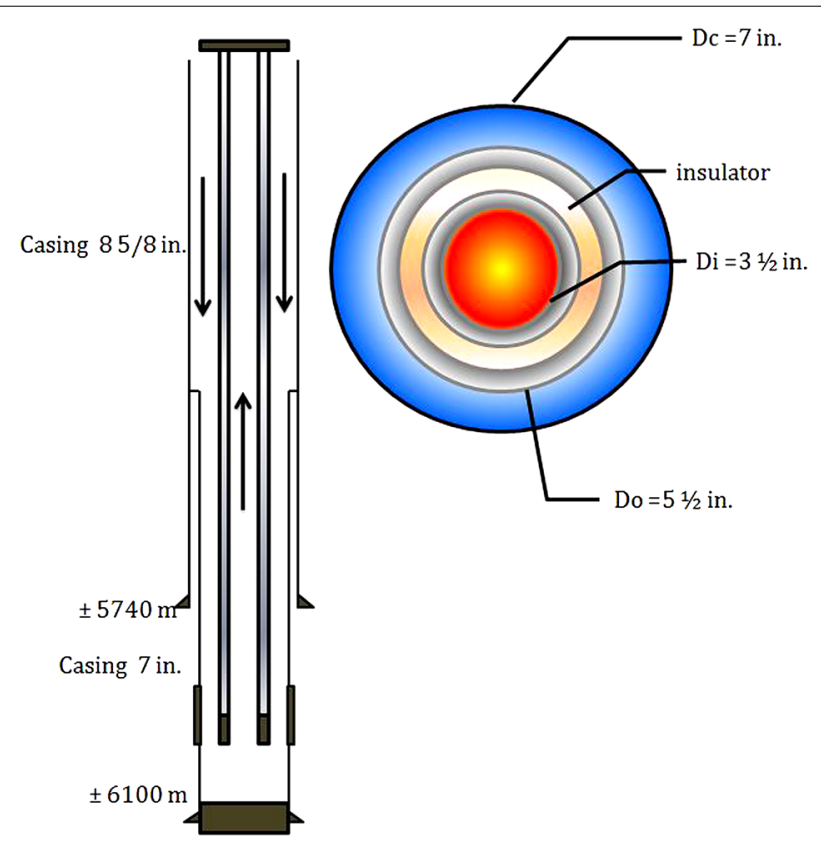

Fig. 7 Configuration of proposed WBHX for the specific case study

Table 1 WBHX tube sizing

\begin{tabular}{lcc}
\hline & Internal diameter $(\mathbf{m m})$ & External diameter $(\mathbf{m m})$ \\
\hline$D_{\mathrm{i}} 3 \frac{1}{2}$ in. & 77.9 & 88.9 \\
$D_{0} 5 \frac{1}{2}$ in. & 121.4 & 139.7 \\
$D_{c}$ casing 7 in. & 150.4 & 177.8 \\
\hline
\end{tabular}




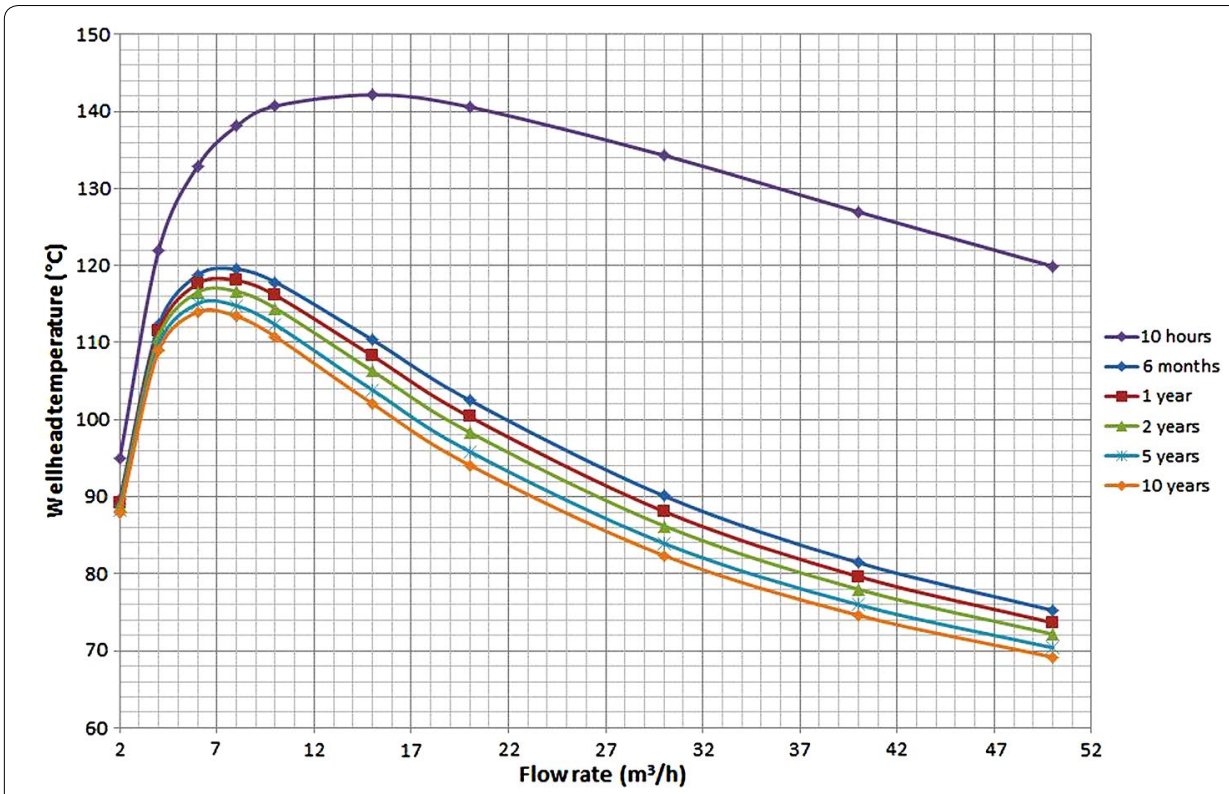

Fig. 8 Wellhead temperature versus flow rate

bottomhole temperature of the water due to the drop of the temperature at the WBHX wall. After 6 months, the system tends to a steady state condition. At the flow rate of $8 \mathrm{~m}^{3} / \mathrm{h}$ the wellhead temperature has a maximum around $120^{\circ} \mathrm{C}$, and the temperature decrease is less than $10^{\circ} \mathrm{C}$ after 10 years.

Having fixed the exit temperature $T_{0}$ from the ORC power plant or the Stirling motor the thermal power TP has been evaluated using the following relations:

$$
\mathrm{TP}=c_{\mathrm{P}} \cdot \rho \cdot q \cdot\left(T-T_{0}\right)
$$

$c_{\mathrm{p}}$ is the specific heat of water, equal to $4186 \mathrm{~J} / \mathrm{kg} \mathrm{K}, \rho$ is the water density $\left(\mathrm{kg} / \mathrm{m}^{3}\right), q$ is the water flow rate $\left(\mathrm{m}^{3} / \mathrm{s}\right), T$ is the wellhead temperature of the fluid, $T_{\mathrm{o}}$ is the outlet temperature from the ORC, equal to $40^{\circ} \mathrm{C}$.

The thermal power values are reported in Fig. 9. The decrease of the wellhead temperature in the first 6 months is responsible of the reduction of the extracted thermal power. After 6 months, the thermal power extracted reaches a maximum value between 1.5 and $2 \mathrm{MW}$, depending on the operation time.

The optimization of the WBHX has been carried out with the selection of the $20 \mathrm{~m}^{3} / \mathrm{h}$ value as the working flow rate. Despite the greater values of the wellhead temperature are obtained for the flow rate of 6 and $8 \mathrm{~m}^{3} / \mathrm{h}$, the thermal power tends to grow with the flow rate. For a flow rate of $8 \mathrm{~m}^{3} / \mathrm{h}$ the thermal power is between 650 and $870 \mathrm{~kW}$, depending on the time. For a flow rate of $20 \mathrm{~m}^{3} / \mathrm{h}$ the thermal power is between 1.2 and $2.25 \mathrm{MW}$. Furthermore, if the flow rate exceeds the value of $20 \mathrm{~m}^{3} / \mathrm{h}$ it is necessary to spend energy to circulate the water inside the WBHX (Fig. 10).

In Fig. 11 have been reported the results for a flow rate equal to $20 \mathrm{~m}^{3} / \mathrm{h}$ in the case of continuous power generation up to 10 years from the startup. The decrease of the thermal power between 1 and 10 years is $6.13 \%$, instead the decrease of the bottomhole temperature is $6.45 \%$. So the results after 1 year from the startup have been considered as the most representative ones of the operational condition of the WBHX. 


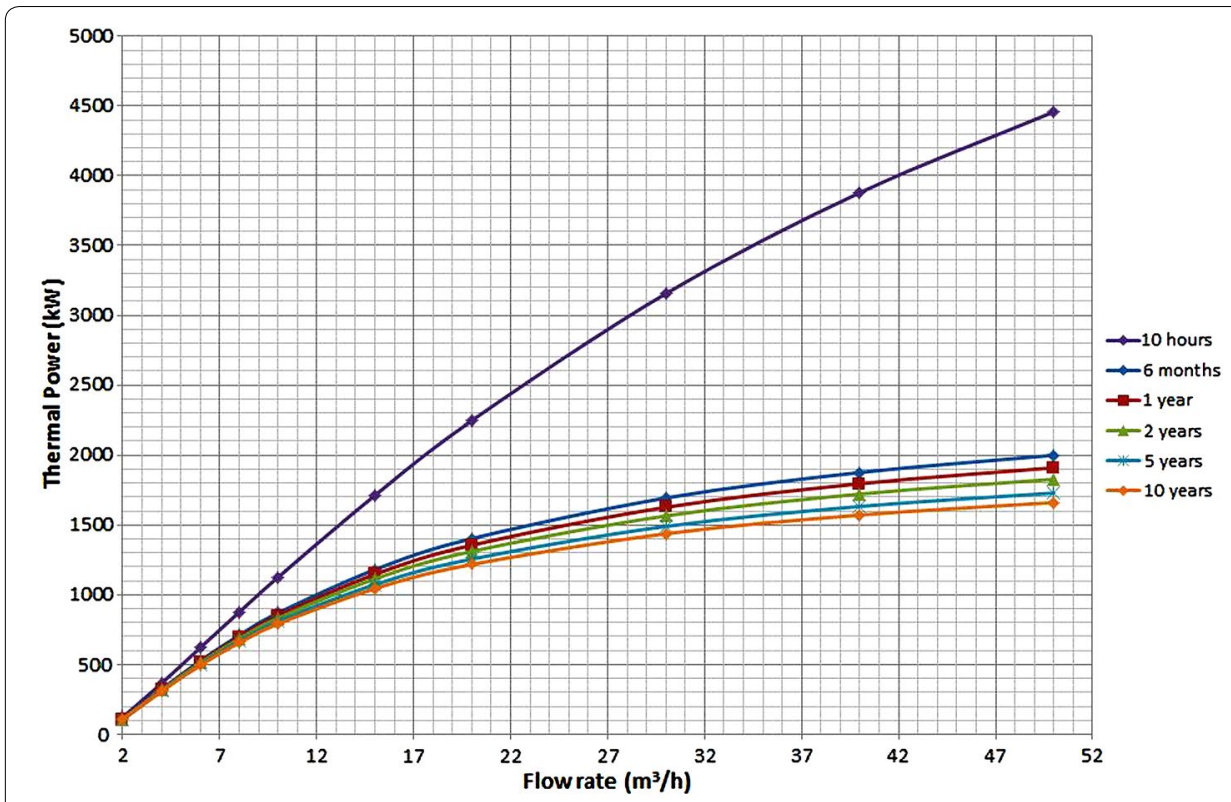

Fig. 9 Thermal power versus flow rate

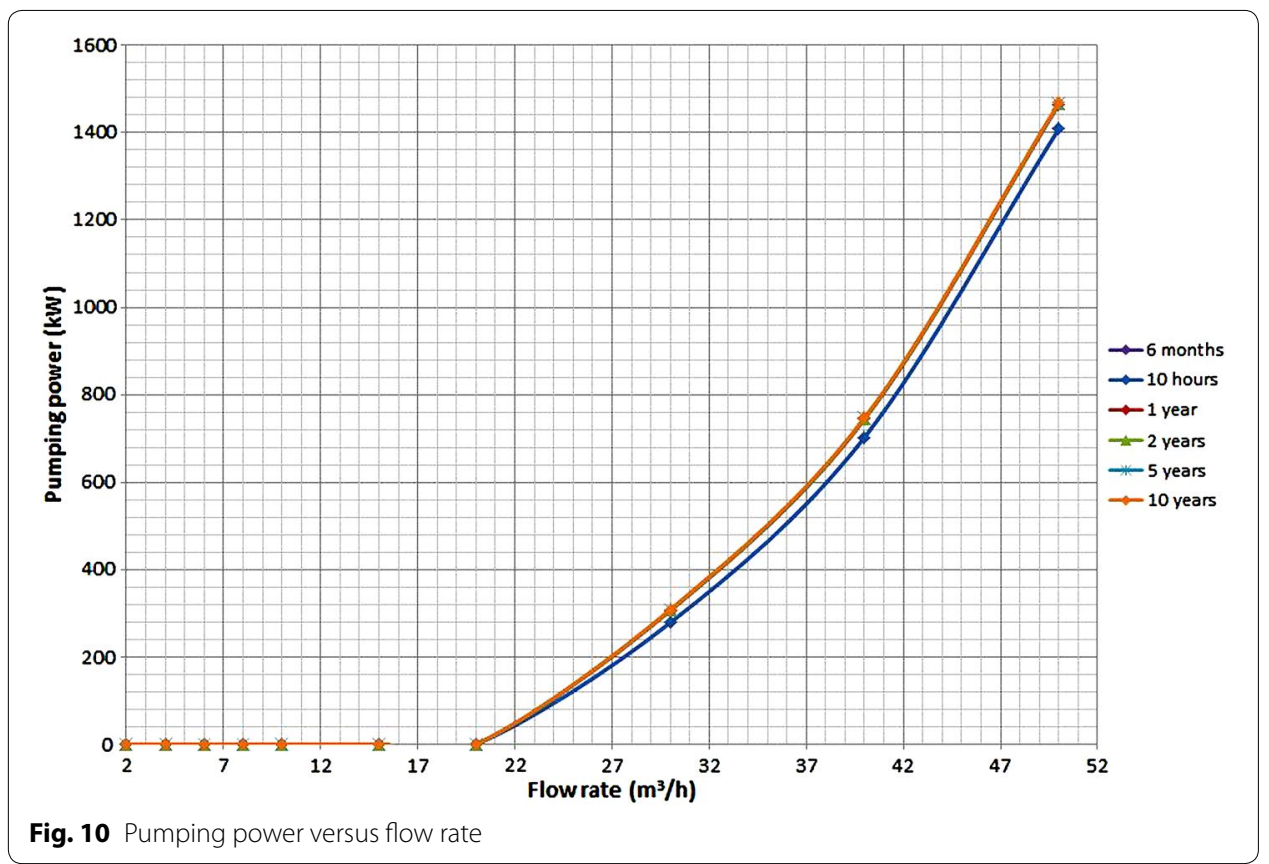

\section{Energy conversion performance: comparison between the two systems}

Having completed the analysis of the WBHX performance, the range of the circulation flow rate and of the exit temperature are known. Summarizing, the thermal power extracted with the WBHX, after 1 year from the start of the plant, is greater than 1.3 MW. The WBHX set of design parameters are $20 \mathrm{~m}^{3} / \mathrm{h}$ for the flow rate, outlet temperature $100.38^{\circ} \mathrm{C}$ and the inlet temperature is $40^{\circ} \mathrm{C}$. 


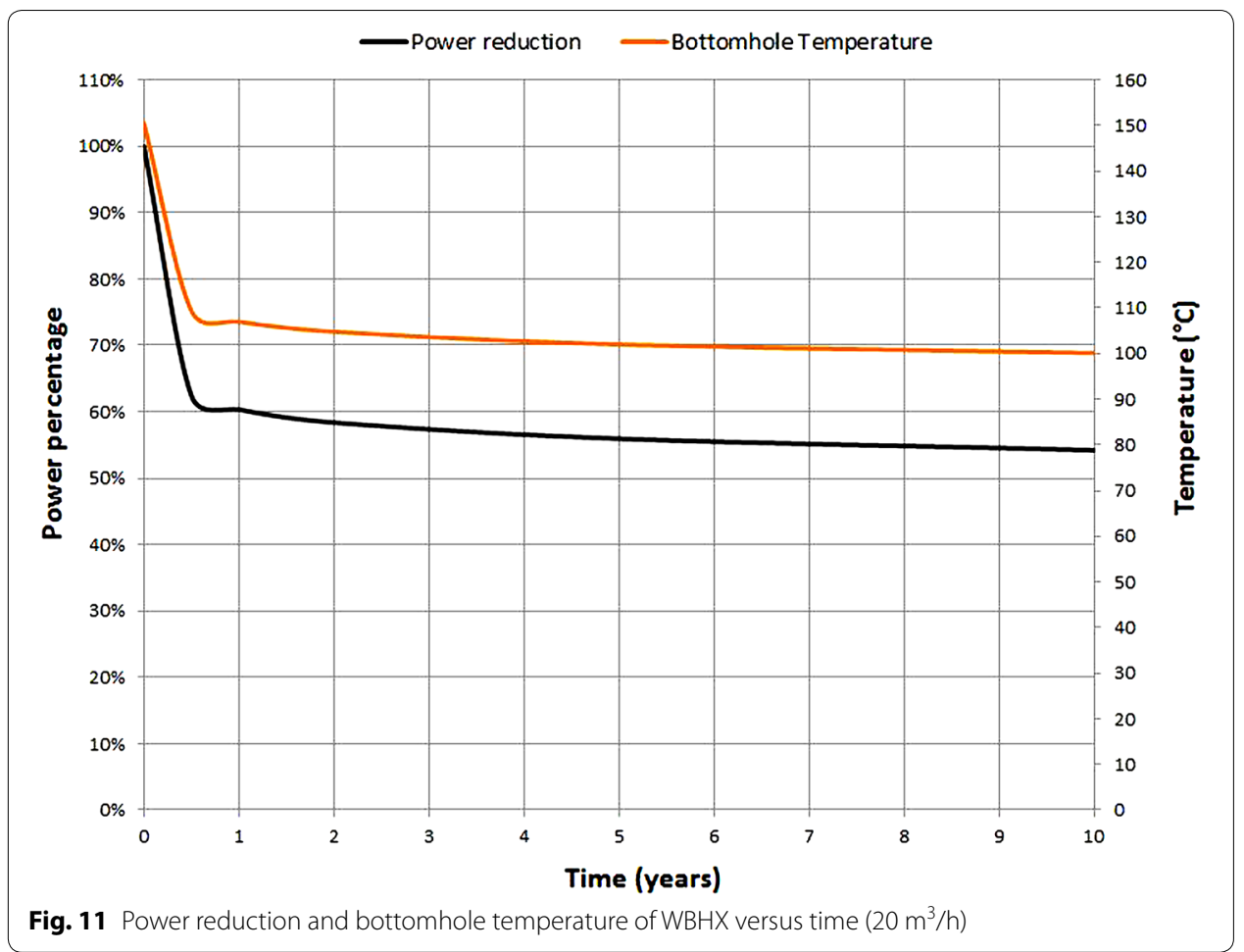

Table 2 Energy conversion performance

\begin{tabular}{lllc}
\hline & Thermal power $(\mathbf{k W})$ & Net electrical power $(\mathbf{k W})$ & Thermal efficiency (\%) \\
\hline ORC power plant & 1355 & 121 & 9.49 \\
Stirling motor & 1355 & 152 & 11.9 \\
\hline
\end{tabular}

The selection of the working fluid of the ORC power plant has been made following the indication from Chen et al. (2010). The R-C318 has been selected as working fluid considering the thermal efficiency and the PH/E ratio (Alimonti and Soldo 2016).

In the evaluation of the performance of the Stirling motor, the working fluid is the air. The maximum volume of the gas is $150 \mathrm{l}$ and a minimum one is $50 \mathrm{l}$.

In Table 2 the results for the two energy conversion systems are reported. The efficiency of the Stirling motor exceeds $25 \%$ the efficiency of the ORC power plant.

On the field of Villafortuna Trecate about 50 wells have been drilled. Only eight are in production. Therefore, in the evaluation of the potential size of the Villafortuna Trecate field it was decided to assume 8 wells available as worst case and 40 wells as best one (Table 3).

\section{Conclusions}

A deep borehole heat exchanger, a closed loop in which a heat carrier fluid circulates and extracts the heat from the surrounding rock without geothermal fluids production, could be an interesting alternative to the conventional doublet systems. The main weakness of the WBHX is the low efficiency in heat recovery respect to the conventional extraction systems. However, the use of a WBHX could be a solution to extract heat 
Table 3 Potential size of the plant

\begin{tabular}{lll}
\hline & Worst case & Best case \\
\hline ORC power plant & $968 \mathrm{~kW}$ & $4.84 \mathrm{MW}$ \\
Stirling motor $(\mathrm{MW})$ & 1.21 & 6.08 \\
\hline
\end{tabular}

from unconventional geothermal systems, whose brines have particular physical and chemical characteristics.

In a previous study (Alimonti and Soldo 2016) has been proposed the application of the WBHX in an oil field: Villafortuna Trecate field, a medium enthalpy geothermal resource. The target was the use of a numerical model to study the feasibility of the WBHX and to optimize the system.

The goal of the present paper is the analysis of the power production of the WBHX in time and the comparison between two different conversion systems of the thermal energy into electrical one: the ORC plant and the Stirling motor.

All the calculations have been done considering different times after the startup of the plant. The simulation results show a substantial decrease of the wellhead temperature in the first 6 months. This phenomenon is due to the progressive enlargement of the influence area of the well and to the drop of the temperature at the WBHX wall. After 6 months, the system tends to an almost steady state condition.

The optimum condition is obtained for a flow rate of $20 \mathrm{~m}^{3} / \mathrm{h}$ and the produced thermal power is $1.3 \mathrm{MW}$ for single well.

The net electrical power is $121 \mathrm{~kW}$ with an ORC power plant and $152 \mathrm{~kW}$ with a Stirling motor. The Stirling engine has an efficiency greater than $25 \%$ compared to a system ORC.

\section{Nomenclature}

\section{Variables}

$A$ : cross-section $\left(\mathrm{m}^{2}\right) ; c_{\mathrm{p}}$ : specific heat capacity $(\mathrm{J} / \mathrm{kg} \mathrm{K}) ; D$ : diameter $(\mathrm{m}) ; h$ : convective heat transfer coefficient $\left(\mathrm{W} / \mathrm{m}^{2} \mathrm{~K}\right) ; k_{\mathrm{t}}$ : total heat transfer coefficient $\left(\mathrm{W} / \mathrm{m}^{2} \mathrm{~K}\right) ; k_{\mathrm{o}}$ : overall heat transfer coefficient $\left(\mathrm{W} / \mathrm{m}^{2} \mathrm{~K}\right) ; R$ : linear thermal resistance coefficient $(\mathrm{K} \mathrm{m} / \mathrm{W})$; $H$ : heat flux (W); $L$ : length (m); Nu: Nusselt number; Pr: Prandtl number; Q: flow rate $\left(\mathrm{m}^{3} / \mathrm{s}\right) ; r$ : radius $(\mathrm{m}) ; R e$ : Reynolds number; $t^{\prime}$ : time $(\mathrm{s}) ; T$ : temperature $(\mathrm{C}) ; V$ : volume $\left(\mathrm{m}^{3}\right)$; $v$ : flow velocity of the fluid $(\mathrm{m} / \mathrm{s}) ; t$ : thickness of composite pipe; $a_{\mathrm{s}}$ : thermal diffusivity $\left(\mathrm{m}^{2} / \mathrm{s}\right) ; \lambda$ : thermal conductivity $(\mathrm{W} / \mathrm{m} \mathrm{K}) ; \lambda_{\mathrm{t}}$ : thermal conductivity of the material of the pipe (W/m K); $\mu$ : dynamic viscosity (Pa s); $v$ : kinematic viscosity $\left(\mathrm{m}^{2} / \mathrm{s}\right) ; \rho$ : density $\left(\mathrm{kg} / \mathrm{m}^{3}\right) ; \eta_{\mathrm{x}}$ : efficiency of the ORC power plant

Index

f: fluid property; a: annular space property; s: rock property; w: wellbore radius; c: casing radius; o: outer radius (of pipe); i: inner radius (of pipe); r: radial component (in pipe); $t$ : total; up: upward; down: downward

\section{Acronyms}

WBHX: wellbore heat exchanger; ORC: organic ranking cycle 


\section{Authors' contributions}

Following are specified the contributions of each author in the research work which is reported in the article and/or in the writing of the paper: CA energy conversion system and introduction. DB abstract and references review. DB evaluation of the results. ES heat transfer model and conclusions. All authors read and approved the final manuscript.

\section{Acknowledgements}

The authors declare that no other contributors have provided technical or writing assistance.

\section{Competing interests}

The authors declare that they have no competing interests.

Received: 9 February 2016 Accepted: 8 September 2016

Published online: 19 September 2016

\section{References}

Alimonti C, Soldo E. Study of geothermal power generation from a very deep oil well with a wellbore heat exchanger. Renew Energy. 2016;86:292-301.

Altmann JB, Heidbach O, Gritto R. Relative importance of processes leading to stress changes in the geysers geothermal area. In: Proceedings of thirty-eighth workshop on geothermal reservoir engineering 2013, Stanford University, Stanford, California, USA.

Asanuma H, Eto T, Adachi M, Saeki K, Aoyama K, Ozeki H, Häring M. Seismostatistical characterization of earthquakes from geothermal reservoirs. In: Proceedings of thirty-ninth workshop on geothermal reservoir engineering 2014, Stanford University, Stanford, California, USA.

Axelsson G. Role and management of geothermal reinjection. In: Presented at short course on geothermal development and geothermal wells 2012, organized by UNU-GTP and LaGeo, in Santa Tecla, El Salvador.

Bennett CO, Myers JE. Momentum, heat, and mass transfer. McGraw-Hill; 1982.

Bolognesi L. The oxygen isotope exchange between carbon dioxide and water in the Larderello geothermal field (Italy) during fluid reinjection. Geothermics. 2011;40(3):181-9.

Brodsky EE, Lajoie LJ. Anthropogenic seismicity rates and operational parameters at the Salton sea geothermal field. Science. 2013;341:543-6.

Bu X, Ma W, Li H. Geothermal energy production utilizing abandoned oil and gas wells. Renew Energy. 2012;41:80-5.

Capetti G, Parisi L, Ridolfi A, Stefani G. Fifteen years of reinjection in the Larderello-Valle Secolo area: analysis of the production data. In: Proceedings of world geothermal congress 1995, Florence, Italy.

Carslaw HS, Jaeger JC. Conduction of heat in solids. 2nd ed. Oxford: Oxford Clarendon Press; 1959.

Chen H, Goswami DY, Stefanakos EK. A review of thermodynamic cycles and working fluids for the conversion of lowgrade heat. Renew Sustain Energy Rev. 2010;14:3059-67.

Cheng WL, Li TT, Nian YL, Wang CL. Studies on geothermal power generation using abandoned oil wells. Energy. 2013;59:248-54

Cheng WL, Li TT, Nian YL, Wang CL. Evaluation of working fluids for geothermal power generation from abandoned oil wells. Appl Energy. 2014;118:238-45.

Churchill SW. Friction-factor equation spans all fluid-flow regimes. Chem Eng. 1977;84(24):91-2.

Davis AP, Michaelides EE. Geothermal power production from abandoned oil wells. Energy. 2009;34:866-72.

Diaz AR. Reinjection in geothermal fields: a worldwide review update. In: Proceedings of world geothermal congress 2015, Melbourne, Australia.

Evans KF, Zappone A, Kraft T, Deichmann N, Moia F. A survey of the induced seismic responses to fluid injection in geothermal and CO2 reservoirs in Europe. Geothermics. 2012;41:30-54

Flóvenz OG, Ágústsson K, Guð̌nason EÁ, Kristjánsdóttir S. Reinjection and induced seismicity in geothermal fields in Iceland. In: Proceedings of world geothermal congress 2015, Melbourne, Australia, 19-25 April 2015.

Giovannoni A, Allegrini G, Cappetti G, Celati R. First results of reinjection experiment at Larderello. In: Proceedings of 7th workshop on geothermal reservoir engineering 1981, Stanford University, Stanford, CA. p. 77-83.

Goyal KP, Conant TT. Performance history of the Geysers steam field, California, USA. Geothermics. 2010;39:321-8.

Gunnarsson G. Mastering reinjection in the Hellisheidi Field, SW-Iceland: a story of successes and failures. In: Proceedings of thirty-sixth workshop on geothermal reservoir engineering 2011, Stanford University, Stanford, California, USA.

Gunnarsson G, Kristjánsson BR, Gunnarsson I, Júlíusson BM. Reinjection into a fractured reservoir-induced seismicity and other challenges in operating reinjection wells in the Hellisheiði Field, SW-Iceland. In: Proceedings world geothermal congress 2015, Melbourne, Australia, 19-25 April 2015.

Hance CN. Factors affecting costs of geothermal power development. Geothermal Energy Association for the US Department of Energy 209 Pennsylvania Avenue SE, Washington, DC, August 2005.

Itoi R, Fukuda M, Jinno K, Shimizu S, Tomita T. Numerical analysis of the decrease in injectivity of wells in the Otake geothermal field, Japan. In: Proceedings of 9th NZ geothermal workshop 1987.

Kenedi CL, Shalev E, Lucas A, Malin P. Microseismicity and 3-D mapping of an active geothermal field, Kilauea Lower East Rift Zone, Puna, Hawaii. In: Proceedings of world geothermal congress 2010, Bali, Indonesia.

Kolin I, Koscak-Kolin S, Golub M. Geothermal electricity production by means of the low temperature difference Stirling engine. In: Proceedings of world geothermal congress 2000, Kyushu-Tohoku, Japan.

Kujawa T, Nowak W, Stachel AA. Utilization of existing deep geological wells for acquisitions of geothermal energy. Energy. 2006;31:650-64

Liu J, Wang K. Geothermal reinjection in China. In: Proceedings of the 7th Asian geothermal symposium 2006. 
Lloyd CC. A low temperature differenrtial Stirling engine for power generation. A master's thesis, University of Canterbury, New Zeland, 2009

Malate RCM, O'Sullivan MJ. Modelling of chemical and thermal changes in well PN-26 Palinpinon geothermal field, Philippines. Geothermics. 1991;20:291-318.

Melinder A. Doctoral thesis: thermophysical properties of aqueous solutions used as secondary working 2007 division of applied thermodynamics and refrigeration Dept. of Energy Technology School of Industrial Engineering and Management, Royal Institute of Technology, KTH Stockholm, Sweden.

Nalla G, Shook GM, Mines GL, Bloomfield KK. Parametric sensitivity study of operating and design variables in wellbore heat exchangers. Geothermics. 2005;34:330-46

Noé EC, Pulido CL, Peredo JS, Arreola SP. Micro seismic monitoring during production. Utilization and case examples for México. Geotermia. 2013;26:33-45.

Pramono B, Colombo D. Microearthquake characteristics in Darajat geothermal field, Indonesia. In: Proceedings of world geothermal congress 2005, Antalya, Turkey.

Sherburn S, Bourguignon S, Bannister S, Sewel S, Cumming B, Bardsley C, Quinao J, Wallis I. Microseismicity at Rotokawa geothermal field, 2008 to 2012. In: Proceedings, 35th New Zealand geothermal workshop 2013, Rotorua, New Zealand.

Stefánsson V. Geothermal reinjection experience. Geothermics. 1997;26:99-139.

Templeton JD, Ghoreishi-Madiseh SA, Hassani F, Al-Khawaja MJ. Abandoned petroleum wells as sustainable sources of geothermal. Energy. 2014;70:366-73.

Urban E, Lermo JF. Local seismicity in the exploitation of Los Humeros geothermal Field, Mexico. In: Proceedings of thirtyeighth workshop on geothermal reservoir engineering 2013, Stanford University, Stanford, California, USA.

Wang Z, McClure MW, Horne RN. A single-well EGS configuration using a thermosiphon. In: Proceedings of thirty-fourth workshop on geothermal reservoir engineering, Stanford University 2009, Stanford, California.

Zhang L, Yuan J, Liang H, Li K. Energy from abandoned oil and gas reservoirs. In: Proceedings of Asia pacific oil and gas conference and exhibition 2008, Perth, Australia.

\section{Submit your manuscript to a SpringerOpen ${ }^{\circ}$ journal and benefit from:}

- Convenient online submission

Rigorous peer review

- Immediate publication on acceptance

Open access: articles freely available online

- High visibility within the field

Retaining the copyright to your article

Submit your next manuscript at $\gg$ springeropen.com 